\title{
MENELUSURI MAKNA DRAMA FAUST I KARYA J. W. VON GOETHE
}

\begin{abstract}
Abstrak
Penelitian ini bertujuan untuk mendeskripsikan makna tanda-tanda dalam drama Faust I, yang berkaitan dengan hubungan antara manusia dan setan. Drama Faust I dianalisis posisinya dalam kesusasteraan Jerman, struktur dan teksturnya. Drama Faust I dianalisis melalui dua tahap pembacaan, yakni pembacaan heuristik dan pembacaan hermeneutik, dan setelah itu diidentifikasi matriks, varian, hipogram dan hubungan intertekstualnya. Dalam drama Faust I, Goethe ingin menegaskan keberadaan manusia yang mengadakan hubungan dengan setan karena hasratnya untuk menguasai ilmu pengetahuan. Hasrat yang tinggi terkendala oleh keterbatasan sehingga manusia menempuh jalan yang salah bersekutu dengan setan.
\end{abstract}

Isti Haryati

FBS Universitas Negeri Yogyakarta

email: haryati.istihar@gmail.com

Kata kunci: drama, tanda semiotik, hipogram

\section{TRACING MEANINGS IN J. W. VON GOETHE'S FAUST I}

\begin{abstract}
This study aims to describe the meanings of the signs in the Faust I drama script in terms of the relationship between human beings and the Satan. Its position in German literature, structure, and texture were analyzed. It was analyzed through two reading stages, namely heuristics and hermeneutics; then, the matrix, variance, hypogram, and intertextual relationship were analyzed. In Faust I, Goethe wishes to emphasize the existence of human beings who establish relationship with the Satan because of their desire to acquire scientific knowledge. The strong desire is constrained by limitation, making them take a wrong path by establishing relationship with the Satan.
\end{abstract}

Keywords: drama, semiotic signs, hypograms

\section{PENDAHULUAN}

Dalam lingkungan kesusastraan Jerman, nama Faust sudah melegenda. Kisah seorang doktor pada abad pertengahan yang mahir ilmu sihir dan bersekutu dengan setan menjadi bagian penting dalam kehidupan kesusastraan Jerman. Kisah tersebut menjadi populer karena ketokohannya merupakan saksi kebangkitan individualisme di Eropa. Karena kepopulerannya, kisah tentang Faust banyak ditulis oleh pengarang di Jerman dari masa ke masa. Sampai sekarang, tercatat lebih kurang 20.000 karya sastra yang membahas kehidupan Faust sehingga dikatakan bahwa Faust adalah cermin sejarah masyarakat Jerman (Faust als Spiegel der Geschichte).

Johann Wolfgang von Goethe (atau disebut Goethe) adalah salah seorang sastrawan Jerman yang menulis karya sastra tentang Faust ini. Ketertarikannya terhadap kisah tersebut menggerakkan Goethe menulis dan menggubahnya dalam bentuk drama. Masa penciptaan kisah Faust ini mencapai waktu 38 tahun dari mulai periode Sturm und Drang sampai pada masa Klasik. Faust eine Tragödie (Faust I) selesai diciptakan pada periode Klasik (1808) dan sembilan bulan sebelum kema- 
tiannya pada tahun 1832, Goethe berhasil menyelesaikan drama Faust bagian II (Faust Zweiter Teil).

Drama Faust I adalah sebuah tragedi (Tragödie) yang ditandai dengan adanya konflik tragis yang dialami oleh tokoh utama, yaitu Faust. Selain pada tokoh Faust, tragedi juga terjadi pada tokoh penting lain, yakni Gretchen. Tragedi yang terjadi pada tokoh Faust dan Gretchen, menjadi dua tema penting dalam drama Faust I. Dua tema tersebut, yaitu tema tragedi seorang intelek (Gelehrtentragödie) yang mengadakan perjanjian dengan setan dan tema tragedi Gretchen yang membunuh anak yang dilahirkan (Gretchentragödie), menjadi tema aktual meskipun karya tersebut ditulis beberapa abad yang silam.

Faust I adalah karya sastra berbentuk drama tragedi. Sebagai drama, Faust I bisa dilihat dari dua dimensi, yakni dimensi drama sebagai karya sastra dan dimensi drama sebagai karya pertunjukan. Sebagai teks sastra, drama Faust I mempunyai aspek-aspek tertentu yang berbeda dengan karya drama yang dipentaskan. Oleh karena itu, proses pemaknaan drama sebagai teks juga berbeda dengan pemaknaan drama sebagai karya pertunjukan (teater). Penelitian ini membahas drama Faust I sebagai teks sastra dan bukan drama yang dipentaskan (teater).

Drama Faust I adalah karya sastra yang harus dimaknai. Pemaknaan teks drama Faust I sebagai karya sastra dilakukan dengan mencari tanda-tanda dalam teks drama tersebut dan memaknainya. Dalam penelitian ini, makna drama Faust I sebagai karya sastra dicari dengan mencari tanda-tanda yang penting. Oleh karena itu, teori yang cocok digunakan sebagai landasan analisis terhadap drama Faust I ini adalah teori yang mempelajari tanda atau semiotik. Tanda-tanda yang penting dalam drama Faust I ini dicari dan dimaknai dengan menggunakan pisau Semiotika Riffaterre. Pradopo (2005: 4) mengatakan, bahwa teori semiotika Riffaterre mengemukakan metode pemaknaan khusus, tetapi pemaknaannya tidak terlepas dari pemaknaan semiotik pada umumnya. Menurut Riffaterre, karya sastra adalah dialektika antara teks dan pembaca (a dialectic between text and reader). Selain itu, yang penting dalam semiotika Riffaterre adalah memahami teks-teks yang melatarbelakangi penciptaan teks yang lahir yang oleh Riffatterre disebut hipogram (Riffatterre, 1984: 23). Dengan melihat teks yang menjadi rujukan pengarang dalam menulis sebuah teks dan kemudian melihat hubungan intertekstualnya maka makna teks akan menjadi lebih jelas.

Dalam bukunya yang berjudul Semiotics of Poetry (1984), Riffaterre mengemukakan pengertian puisi yang tidak hanya membawa nuansa baru, tetapi juga membuatnya dekat dengan semiotika, yaitu bahwa sebuah puisi mengatakan sesuatu yang berbeda dari makna yang dikandungnya (a poem says one thing and means another). Riffattere menyebut gerakan atau strategi tersebut sebagai ketidaklangsungan (indirection). Ada empat hal yang harus diperhatikan dalam pemaknaan puisi atau karya sastra menurut Riffaterre, yakni (1) puisi itu merupakan ekspresi yang tidak langsung, (2) pembacaan heuristik dan hermeneutik, (3) matriks, model, dan varian dan (4) hipogram. Dalam memaknai karya sastra yang berbentuk puisi, keempat hal tersebut bisa dilakukan, tetapi untuk memaknai karya sastra yang berbentuk prosa dan drama, tidak semua aspek diterapkan.

Untuk memahami semiotika puisi (karya sastra), dilakukan dua tahap pembacaan terhadap karya sastra, yakni heuristik dan hermeneutik. Menurut Riffaterre sebelum mencapai signifikansi, pembaca harus menangani mimesis (Riffaterre, 1984: 5-6). Pembacaan tahap kedua merupakan pembacaan retroaktif, yaitu pembacaan yang didasarkan pada konvensi 
sastra, merupakan saat interpretasi yang kedua, bagi pembacaan yang benar-benar hermeneutik.

Selain itu, yang penting juga dalam Semiotika Riffaterre adalah adanya matriks, varian, model dan hipogram. Matriks merupakan konsep abstrak dan dapat berupa satu kata atau satu kalimat yang tidak selalu teraktualisasikan di dalam teks. Hipogram adalah ruang kosong yang tidak ada secara tekstual, tetapi yang menentukan terbentuknya puisi ini. Hipogram ini dapat dibedakan menjadi dua, yakni hipogram potensial dan hipogram aktual. Hipogram potensial adalah segala bentuk implikasi makna kebahasaan, baik yang berupa presuposisi (penganggapan) bahasa, makna-makna konotatif yang sudah dianggap umum, dan sebagainya. Hipogram aktual menjadi latar penciptaan teks baru. Hipogram aktual terwujud dalam teks-teks yang sudah ada sebelumnya, baik yang berupa mitos maupun karya sastra lainnya. Dari hipogram, terbentukah hubungan interteks antara teks yang menjadi hipogram dan teks transformasinya.

\section{METODE}

Sumber data pada penelitian ini adalah teks drama Faust I karya Johann Wolfgang von Goethe yang diterbitkan oleh Diogenes Verlag AG, Jerman pada tahun 1982. Teks drama ini terdiri atas 3 praadegan dan 25 adegan (Szene). Data pada penelitian ini adalah tanda-tanda semiotik yang berkaitan dengan hubungan antara manusia dan setan dalam drama Faust I dan dicari maknanya dengan menggunakan semiotika Riffaterre.

Berkaitan dengan penelitian sastra sebagai bentuk penelitian kepustakaan, metode yang dimanfaatkan pada penelitian ini lebih tepat mengarah pada metode penelitian kualitatif. Metode penelitian kualitatif merupakan metode penelitian yang menghasilkan penemuan-penemuan yang tidak dapat dicapai dengan meng- gunakan prosedur-prosedur statistik atau kuantitatif (Moleong, 2007: 6).

Cara kerja yang ditempuh dalam penelitian ini pertama dengan melakukan kajian terhadap drama Faust I dalam kesusastraan Jerman, dan kemudian membedah makna drama Faust I dengan menggunakan teori semiotika Riffaterre. Langkah-langkah kerja dalam penelitian ini dengan menggunakan teori semiotika Riffaterre sebagai berikut. Pertama, menetapkan objek penelitian, yaitu drama Faust I karya Johann Wolfgang von Goethe, melakukan studi pustaka untuk mencari dan mengumpulkan data-data yang mendukung objek penelitian. Kedua, melakukan kajian terhadap drama Faust I dalam sastra Jerman. Ketiga, melakukan pembacaan heuristik terhadap drama Faust I. Keempat, melakukan pembacaan hermeneutik terhadap drama Faust I. Kelima, mencari matriks, model, dan varian-varian drama Faust I serta memaknai drama Faust I berdasarkan hipogramnya. Keenam, membuat kesimpulan dan melaporkan hasil penelitiaan.

\section{PEMBAHASAN \\ Drama Faust I Dalam Kesusastraan Jer- man}

Dalam sejarah kesusastraan Jerman (Deutsche Literaturgeschichte), drama Faust I karya Johann Wolfgang von Goethe masuk dalam periode klasik (Baumann, 2000: 112, Rötzer, 1992: 110, Freund, 2000 : 90). Periode klasik di Jerman berlangsung mulai tahun 1786 sampai tahun 1805 . Pembatasan waktu periode klasik di Jerman diawali dengan kepergian Goethe ke Italia (1876) dan diakhiri dengan meninggalnya Schiller (1805). Periode klasik adalah periode setelah sastrawan mencapai tingkat kedewasaan dan kematangan, setelah melalui masa penuh gejolak pada masa Sturm und Drang.

Secara ringkas, dapat dikemukakan bahwa karya sastra pada jaman klasik diciptakan dari kepercayaan pada cita- 
cita kemanusiaan yang terpenuhi dan sempurna, kepercayaan tentang manusia ideal, dan kepercayaan tentang kenyataan yang tidak terpenuhi dan tidak sempurna (Freund, 2000: 81). Gambaran ideal karya sastra pada periode klasik (Weimarer Klasik) adalah tentang alam dan dunia, yang merupakan organisme yang teratur, bebas dari kesewenang-wenangan dan kekerasan. Ketentuan manusia yang tertinggi merupakan perkembangan yang harmonis dari semua kekuatan, dari kematangan, dan pemurnian tumbuh penyatuan dengan jiwa dunia.

Sebagaimana karya sastra yang ditulis pada periode klasik, drama Faust I ditulis dalam bentuk bait-bait puisi berima (kecuali dalam Szene Trüber Tag). Pemakaian rima akhir menghasilkan keindahan bunyi dalam setiap dialog dalam drama Faust I. Aturan yang ketat dalam penulisan puisi dan drama, merupakan salah satu ciri khas karya sastra periode klasik. Hal tersebut disebabkan, menurut Goethe, hanya dalam bentuk puisi yang indah dapat tercipta isi atau makna yang sempurna. Keindahan akan mendukung terciptanya manusia yang ideal dan sempurna (Freund, 2000: 80). Selain itu, ciri khas lain drama Faust I karya Goethe bertujuan menciptakan manusia ideal, menge tengahkan nilai humanisme, dan berkisah tentang persoalan jati diri (eksistensi) manusia.

Tokoh Faust, dalam drama Faust I, ingin menjadi manusia ideal, manusia ideal yang ingin diwujudkan dalam periode klasik ini. Manusia ideal adalah manusia yang mempunyai keseimbangan atau harmonisasi antara jiwa dan raga, nafsu jasmani dengan moralitas, penampilan dengan sikap. Dalam diri Faust, keinginan untuk menjadi manusia yang ideal begitu menggebu-gebu sehingga dia mencoba untuk mempelajari hampir semua ilmu pengetahuan untuk mencapai ambisinya itu (Goethe, 1982: 17). Akan tetapi, Faust tidak pernah merasa puas de- ngan apa yang dicapainya sehingga akhirnya menempuh jalan yang salah, yakni mengadakan perjanjian dengan setan Mephistopheles.

Yang menonjol dari drama Faust I, sebagai karya sastra periode klasik, adalah persoalan jati diri (eksistensi) manusia. Faust adalah manusia yang merasa kehilangan jati dirinya sebagai manusia. Semenjak percakapan Tuhan dengan setan Mephistopheles, Faust muncul mewakili manusia yang mengabdi kepada Tuhan, yang bingung mencari bentuk pengabdiannya kepada Tuhan. Dalam pencariannya itu, Faust tergelincir dan masuk perangkap setan Mephistopheles yang dari awal memang berniat menggodanya. Berbagai tawaran kemudahan hidup, yang tujuannya adalah untuk membantu Faust menemukan jati dirinya, diberikan oleh Mephistopheles. Melalui proses pertaruhan, tawaran itu diterima meskipun itu berarti Faust telah menggadaikan jiwanya kepada setan. Faust yakin bahwa Mephistopheles tidak akan pernah bisa memuaskan dirinya sehingga dia tidak akan kalah dalam pertaruhan itu (Goethe, 1982: 54).

Drama Faust I adalah sebuah tragedi. Oleh karena itu, permasalahan yang muncul di dalamnya adalah adanya tragedi yang terjadi pada tokoh-tokohnya, yakni pada diri Faust dan Gretchen. Tragedi pada diri Faust yang terkenal dengan nama Gelehrtentragödie adalah tragedi seorang ilmuwan yang mengadakan perjanjian dengan setan. Apabila seorang ilmuwan yang juga pemikir dikuasai oleh setan, maka yang terjadi adalah kerusakan-kerusakan di muka bumi. Setan akan selalu mengarahkan manusia untuk berbuat kerusakan di muka bumi ini. Tragedi pada tokoh yang lain adalah tragedi pada diri Gretchen, seorang wanita yang menjadi kekasih Faust, dan terkenal dengan nama Gretchentragödie. Tragedi pada dirinya yang harus dihukum mati karena membunuh anak yang baru dilahirkan 
adalah tragedi yang merupakan efek perjanjian Faust dengan setan.

\section{Struktur dan Tekstur Drama Faust I}

Drama Faust I diciptakan oleh Goethe dalam rentang waktu yang lama, yakni 36 tahun. Drama Faust I mulai ditulis pada tahun 1772 dalam bentuk drama berjudul Urfaust, kemudian dikembangkan menjadi Faust, ein Fragmen pada tahun 1788 dan akhirnya disempurnakan menjadi Faust, eine Tragödie (Faust I) yang diselesaikan pada tahun 1808. Drama Faust I terdiri atas 25 adegan dan tiga praadegan yang terdiri atas persembahan (Zueignung), babak pembuka (Vorspiel) dan prolog (Pro$\log )$. Hampir seluruh adegan dalam drama Faust I diuntai dalam bentuk bait yang berima (im reimenden Versen geschrieben), kecuali adegan ke-23 (Trüber Tag, Feld) yang ditulis dalam bentuk narasi (im Prosa geschrieben).

Dari analisis terhadap struktur drama berupa tokoh disimpulkan bahwa tokoh protagonis dalam drama Faust I adalah Faust, tokoh antagonis adalah Mephistopheles, serta didampingi tokoh-tokoh lain seperti Gretchen, Nyonya Marthe, Wagner, Lischen, dan Valentin. Selain itu, masih banyak pelaku lain yang muncul dalam drama Faust I ini sehingga jumlah pelaku 80 orang.

Sebagai tokoh utama dalam drama Faust I ini, Faust memperkenalkan diri secara langsung dalam monolognya sebagai seorang doktor pandai yang hampir menguasai semua ilmu.

"Habe nun ach,! Philosophie, Juristererei und Medizin

Und, leider! Auch Theologi

Durchaus studiert. Mit heißem Bemuhn. Da steh ich nun, ich armer Tor!

Und bin so klug, als wie zuvor! " (Goethe, 1982: 17).

("Ah, semua telah kupahami! Filsafat, Ilmu hukum dan kedokteran. Bahkan, sayangnya! Juga Teologi. Dengan sangat giat, habis tuntas kupelajari.
Beginilah aku sekarang, si gila yang malang. Pandai seperti dulu, tak lebih dan tak kurang")

Dari monolognya tersebut, terlihat bagaimana karakter Faust yang emosional dan tidak pernah puas, merasa tidak mempunyai apa pun di dunia ini seperti harta, uang, kehormatan maupun kenikmatan duniawi. "Auch hab ich weder Gut noch Geld, Noch Ehr und Herrlichkeit in der Welt. ("Juga aku tak punya harta maupun uang, tak punya kehormatan maupun kesenangan duniawi") (Goethe, 1982: 1). Karena ketidakpuasannya, Faust kemudian mempelajari ilmu gaib supaya bisa mengungkap beberapa rahasia yang selama ini belum diketahuinya. Selain wataknya yang tidak pernah merasa puas, Faust terlihat sebagai seorang pintar yang kurang percaya diri sehingga untuk menambah kepercayaan dirinya, dia juga mempelajari ilmu gaib (Magie).

Sebelum mengenal tokoh setan Mephistopheles, Faust juga menampakkan kedekatan hubungannya dengan Tuhan (Goethe, 1982: 35-36). Kerinduan Faust kepada Tuhan juga diperlihatkan ketika dia mencoba menerjemahkan Injil ke dalam bahasa Jerman. Kerinduan jiwanya akan keindahan tunggal dan sejati, seperti yang tertera di dalam kitab Perjanjian Baru, membuat Faust berniat menerjemahkan kitab tersebut dalam bahasa Jerman (Goethe, 1982: 41).

Setelah Faust mengadakan perjanjian dengan Mephistopheles, Faust mulai terlihat berubah. Keajaiban pertama yang ditunjukkan Mephistopheles kepada Faust adalah membuat Faust menjadi muda kembali dengan bantuan seorang penyihir di sebuah dapur (Hexenkuche). Hal itu dikatakan oleh Mephistopheles, "Auf achtzig Jahr dich zu verjungen!" ("Usiamu delapan puluh tahun, engkau akan dibuat muda kembali") (Goethe, 1982: 74). Dengan minuman itu pula, pandangan Faust terhadap perempuan berubah ka- 
rena semua perempuan terlihat cantik di mata Faust seperti Helena (seorang dewi kecantikan dalam mitologi Yunani).

Perjumpaannya dengan Gretchen, membuat Faust menjadi seorang yang tidak bisa menguasai diri. Rasa cintanya pada Gretchen menyebabkan dia menjadi orang yang egois, tidak mempertimbangkan bahwa cintanya pada Gretchen akan menyebabkan penderitaan pada diri Gretchen. Dalam kondisi yang demikian, Faust begitu mudah dipengaruhi oleh Mephistopheles sehingga akhirnya melakukan perbuatan jahat yang tidak disadarinya.

Alur (Handlung) dalam drama Faust I terdiri atas dua Handlung utama, yakni kisah Faust seorang ilmuwan yang mengikatkan dirinya pada setan dan kisah sedih Gretchen kekasih Faust. Alur dalam drama ini diwarnai oleh konflik yang terjadi antara dua tokoh tersebut, yakni Faust dan Gretchen. Konflik yang terjadi dalam drama Faust I berupa konflik dalam (innerer Konflik) dan konflik luar (außerer Konflik). Konflik dalam (innere Konflik) terjadi karena seorang tokoh mengalami pertentangan antara keinginan dan harapan yang berbenturan satu sama lain. Konflik luar (außerer Konflik) adalah konflik yang terjadi karena pertentangan dengan beberapa kekuatan dalam masyarakat, pertentangan antar-partai, persaingan dalam memperebutkan berbagai kepentingan, misalnya, cinta (Marquass, 1997: 78).

Yang lebih dominan dalam drama Faust I ini adalah konflik dalam yang terjadi pada diri tokoh Faust. Konflik diungkapkan melalui monolog yang panjang. Dalam monolognya, Faust berkata pada dirinya sendiri bagaimana dia mengalami ketidakpuasan dalam dirinya. Ketidakpuasan itu disebabkan Faust merasa belum menemukan makna kehidupan di dunia ini. Berbagi disiplin ilmu yang telah ia tempuh, bahkan ilmu sihir ia pelajari, tetapi dia belum merasa puas. Konflik dalam diri tokoh Faust begitu memuncak sehingga Faust merasa sangat berputus asa dan merasakan bahwa bunuh dirilah jalan yang tepat untuk menyelesaikan konfliknya. Dengan secangkir minuman racun dia mencoba untuk bunuh diri. "Der letzte Trunk sei nun mit ganzer Seele. Als festlich hoher Gruß dem Morgen zugebracht". ("Ini adalah minuman terakhir, dengan seluruh jiwa, sebagai salam agung yang kusampaikan kepada pagi") (Goethe, 1982: 27). Untunglah pada saat yang genting, Faust mendengar bunyi lonceng gereja dan paduan suara yang menyanyikan kebangkitan Yesus Kristus sehingga Faust tersadar dan terhindar dari perbuatan sesat.

Konflik batin (innerer Konflik) juga terjadi pada tokoh Gretchen. Konflik diungkapkan oleh Gretchen melalui monolog yang diucapkannya. Konflik batin Gretchen terjadi karena pertemuannya dengan Lieschen, sahabatnya. Lieschen menceritakan temannya bernama Bärbelchen, yang mendapatkan sangsi dari gereja dan masyarakat karena berhubungan cinta dengan seorang laki-laki dan sekarang telah ditinggalkan kekasihnya. Kondisi dirinya yang hampir mirip dengan Bärbelchen membuat Gretchen mengalami konflik batin. Kondisi itu semakin parah ketika menjelang kematiannya, Valentin kakaknya mengutuknya sebagai seorang pelacur. Perasaan bersalah mendera batinnya, ketika dia sendiri maupun ketika bersama orang-orang lain." Weh! Weh! Wär ich der Gedanken los, die mir herüber und hinüber gehen wider mich !" ("Aduh! Aduh! Jika saja aku bisa lepas dari pikiran-pikiran ini, yang terus mengikuti ke mana pun aku pergi, menentang diriku!") (Goethe, 1982: 119).

Konflik luar (außerer Konflik) kurang begitu kental dalam drama ini. Konflik luar terjadi karena adanya pertentangan antara dua tokoh, yakni Faust dan Valentin. Faust dan Valentin menjadi pihak yang berseberangan dalam menghadapi Gretchen. Valentin, kakak Gretchen, me- 
rasa bahwa Faust adalah musuh karena Faust telah menodai kehormatan keluarga Valentin. Ketika Valentin melihat Faust, dia berniat membunuhnya. Dalam pertikaian itu, Faust dengan dibimbing oleh Mephistopheles berhasil membunuh Valentin. Faust terpaksa melarikan diri karena perbuatannya itu. Dengan demikian, terjadi juga konflik luar antara Faust dengan masyarakat di lingkungan Gretchen, tempat Faust membunuh Valentin. Kalau Faust tidak melarikan diri, konflik antara mereka akan terjadi secara terbuka. Oleh karena itu, Faust merasa lebih baik menghindar dari konflik tersebut.

Selain antara Faust dan Valentin, konflik luar terjadi juga pada Gretchen dan Valentin. Menjelang kematiannya, Valentin mengatakan kebenciannya kepada Gretchen, Valentin menyebut Gretchen sebagai seorang perempuan mesum yang terkutuk. "Könnt ich dir nur an den dürren Leib, duschändlichkupplerisches Weib". ("Kau cuma kukenal dari tubuhmu yang kering. Kau perempuan celaka.") (Goethe, 1982: 119).

Dari analisis terhadap tekstur drama Faust I ini disimpulkan bahwa dialog merupakan bagian dari Hauptext sehingga pembicaraan tentang dialog tidak terlepas dari Hauptext dan Nebentext. Haupttext dalam drama Faust I terdiri atas 902 dialog dan 6 monolog. Dialog dalam drama Faust I merupakan sumber utama untuk menggali segala informasi tekstual. Drama Faust I mempunyai Haupttext yang lebih dominan daripada Nebentextnya. Nebentext sebagai petunjuk pemanggungan tidak absolut sehingga sehingga sutradara bebas menerjemahkan setiap adegan dalam drama tersebut. Dari pembicaraan mengenai struktur dan tekstur drama Faust I ini tampak bahwa teks drama Faust I menunjukkan satu kesatuan isi, yakni kondisi manusia yang mengadakan perjanjian dengan setan dan efek yang ditimbulkannya. Haupttext dan Nebentext yang ada dalam drama Faust I ini memberi gambaran utuh bagaimana suasana drama ini dari awal hingga akhir yang berubah-ubah dari sedih, kecewa, gembira dan akhirnya berakhir lagi dengan kesedihan sebagaimana karakter sebuah tragedi.

\section{Drama Faust I dalam Pembacaan Heu- ristik dan Hermeneutik}

Pembacaan heuristik merupakan interpretasi pertama terhadap karya sastra. Dengan kata lain, pembacaan heuristik adalah pembacaan berdasarkan struktur bahasanya atau pembacaan yang didasarkan sistem semiotik tingkat pertama (first order semiotics). Pembacaan heuristik pada drama tidak bisa dilakukan seperti pembacaan heuristik pada puisi.

Pembacaan heuristik drama Faust I dilakukan dengan membaca drama ini dari awal hingga akhir. Tiap-tiap adegan dalam drama Faust I diuraikan secara detail. Secara keseluruhan drama Faust $I$ ini terdiri atas tiga pra-adegan, yakni persembahan (Zueignung), babak pembuka (Vorspiel), prolog (Prolog) dan dua puluh lima adegan. Pembacaan heuristik terhadap drama Faust I ini dilakukan dengan mengurutkan cerita dalam drama ini dari awal hingga akhir secara berturutturut, dari pra-adegan yang terdiri atas 3 praadegan dan dilanjutkan dengan membaca tiap-tiap adegan dalam drama ini yang berjumlah 25 adegan. Membaca heuristik dengan menguraikan secara detail tiap-tiap adegannya akan membantu tahap pembacaan berikutnya, yakni pembacaan hermeneutik.

Pembacaan hermeneutik merupakan pembacaan retroaktif, yaitu pembacaan yang didasarkan pada konvensi sastra, merupakan saat interpretasi yang kedua, bagi pembacaan yang benar-benar hermeneutik. Pembacaan hermeneutik adalah pembacaan karya sastra berdasarkan sistem semiotik tingkat kedua (second order semiotics) atau berdasarkan konvensi sastranya. Dalam pembacaan ini, pembaca karya sastra harus bergerak lebih jauh 
untuk memperoleh kesatuan maknanya dari pemahaman makna sebelumnya yang masih beraneka ragam. Gerak pembacaan ini dimungkinkan dan sekaligus didorong oleh adanya rintangan dalam pembacaan pertama.

Oleh karena itu, dalam pembacaan hermeneutik ini yang bersifat ungrammatical dari drama Faust I ditafsirkan berdasarkan konvensi sastra atau berdasarkan sistem semiotik tingkat kedua. Drama Faust I ini dibaca berdasarkan konvensi sastra, yaitu bahwa karya sastra itu merupakan ekspresi yang tidak langsung. Kiasan-kiasan yang merupakan ketidaklangsungan ekspresi dalam drama Faust I ditafsirkan berdasarkan konvensi sastra. Selanjutnya, tanda-tanda penting yang masih gelap dan memerlukan penjelasan diuraikan lebih lanjut dalam pembacaan hermeneutik.

Melalui pembacaan hermeneutik pada drama Faust I, dapat disimpulkan bahwa ketidaklangsungan ekspresi pada drama Faust I yang dominan adalah pada penggantian arti, yaitu metafora. Metafora adalah bahasa kiasan seperti perbandingan tetapi tidak menggunakan kata-kata pembanding. Metafora menyatakan sesuatu hal yang sama atau seharga dengan hal lain, yang sesungguhnya tidak sama. Metafora berupa kalimat dalam drama Faust I ini muncul dalam bentuk persamaan yang tidak menggunakan kata pembanding. Salah satu contoh metafora yang muncul dalam drama Faust I ini adalah dalam adegan Prolog di Surga, yang muncul untuk mempersamakan manusia sebagai Tuhan kecil di dunia. Dialog tersebut diucapkan oleh Mephistopheles ketika menghadap der Herr (Tuhan). Untuk mendapat simpati dari Tuhan, Mephistopheles sebagai setan menjelek-jelekkan kondisi manusia yang saling menyiksa dan menjadi Tuhan kecil di dunia, yang begitu ajaib seperti pada hari pertama diciptakan oleh Tuhan. "Ich sehe nur, wie sich die Menschen plagen. Der kleine Gott der Welt bleibt stets von gleichem Schlag und ist so wunderlich, als wie am ersten Tag" ("Aku hanya melihat betapa manusia saling menyiksa. Tuhan kecil yang ada di dunia, tetap saja yang dulu juga, yang begitu ajaib seperti hari pertama dia tercipta") (Goethe, 1982: 11). Persamaan manusia dengan Tuhan kecil dalam dialog yang diucapkan oleh Mephistopheles menggambarkan kecemburuan Mephistopheles kepada manusia yang mendapatkan keistimewaan pada hari pertama diciptakan sebagai makhluk yang paling sempurna.

Pembacaan hermeneutik berusaha mengungkapkan hal-hal yang belum jelas dalam teks drama ini. Melalui pembacaan secara hermeneutik disimpulkan bahwa tanda penting yang berhubungan dengan hubungan manusia dan setan yang muncul dalam drama Faust I ini, yakni tanda tentang setan, ilmu gaib (Magie), dan perjanjian dengan setan (Teufelspakt). Hubungan manusia dengan setan yang terjadi muncul dalam beberapa bentuk, yaitu dengan mempelajari Magie, mengadakan perjanjian dengan setan dan akhirnya menjual jiwanya kepada setan. Hubungan manusia dengan setan tersebut akhirnya menimbulkan penderitaan pada diri seorang wanita bernama Gretchen.

\section{Matriks, Model, Varian dan Hipogram Drama Faust I}

Matrik drama Faust I ini adalah perjanjian seorang ilmuwan dengan setan untuk bisa mendapatkan makna hidup yang sesungguhnya. Model drama Faust I ini adalah Faust atau Doktor Faust. Kata "Faust" menjadi model dalam drama ini karena kata ini bersifat puistis, kata "Faust" yang dalam arti harafiah berarti kepalan tangan melambangkan kegigihan Faust sebagai seorang ilmuwan dalam menguasai rahasia alam semesta dengan ilmu pengetahuan. Kata tersebut sekaligus bersifat ironi karena kegigihannya dalam menguasai ilmu pengetahuan menyebabkan dia bersedia menjual jiwanya 
kepada setan. Kepuitisan kata Faust karena kata ini bersifat bersifat hipogramatik dan mengacu kepada kisah nyata seorang ilmuwan bernama Doktor Faust/Faustus yang mempelajari ilmu gaib (Magie) dan mengadakan kesepakatan dengan setan. Kisah nyata yang melegenda bahkan menjadi mitos tersebut itulah yang menjadi latar belakang (hipogram) penulisan drama Faust I ini.

Varian-varian yang muncul dalam drama Faust I adalah peristiwa-peristiwa penting dalam drama ini yang merupakan uraian atau penjabaran model dan muncul dari adegan-adegan drama Faust I. Varian pertama model Faust ini adalah peristiwa di surga ketika setan Mephistopheles meminta izin kepada Tuhan agar diperbolehkan menggoda dan membimbing Faust ke jalan yang sesat. Tuhan memberikan izin kepada setan Mephistopheles, dengan catatan bahwa seorang manusia yang baik meskipun dalam tekanan kegelapan, dia tetap akan sadar jalan mana yang baik dan benar.

Varian kedua adalah peristiwa di dalam kamar studi Faust ketika Faust berada dalam puncak kegelisahannya, yang disebabkan oleh ambisinya untuk menguasai rahasia alam semesta. Hal tersebut membuat Faust memutuskan untuk mempelajari Magie (ilmu gaib) meskipun ternyata ilmu tersebut belum membuatnya menjadi puas. Varian ketiga adalah peristiwa bertemunya Faust dengan setan Mephistopheles yang berwujud sebagai anjing pudel berwarna hitam, pada saat Faust berjalan-jalan dengan Wagner, seorang Famulus. Pertemuan tersebut kemudian membuahkan perjanjian yang terjadi di antara keduanya (Teufelspakt). Varian keempat adalah peristiwa di Hexenküche, tempat persinggahan kedua ketika Faust diajak oleh Mephistopheles mengarungi dunia kecil dan dunia besar. Di dapur penyihir tersebut, Faust yang telah berusia 80 tahun dibuat muda kembali dengan ramuan gaib yang disiapkan seorang penyihir wanita. Varian kelima adalah bertemunya Faust dengan gadis muda bernama Gretchen yang menyebabkan keduanya saling jatuh cinta. Cinta menyebabkan Gretchen jatuh ke dalam jurang penderitaan yang dalam. Varian keenam adalah peristiwa di penjara ketika Faust hendak membebaskan Gretchen dari penjara. Gretchen ternyata menolak ajakan Faust dan memilih menyerahkan hidupnya kepada Tuhan daripada mengikuti jalan Faust yang sesat bersama Mephistopheles.

Hipogram adalah teks yang menjadi latar penciptaan sebuah karya sastra (Riffaterre, 1982: 23). Teks yang menjadi hipogram diserap dan ditransformasikan ke dalam teks sesudahnya dan menjadi teks transformasi. Dengan mensejajarkan sebuah teks transformasi dengan teks yang menjadi hipogramya, makna teks akan menjadi lebih jelas. Situasi yang digambarkan menjadi lebih terang sehingga dapat diberikan makna sepenuhnya.

Kristeva (1980: 66), menyatakan bahwa setiap teks merupakan hasil kutipan, peresapan, dan transformasi teks-teks lain (Any text is constructed as a mosaic of quotations, any text is the absorbtion and transformation of another"). Pendapat yang dikemukakan oleh Kristeva tersebut terkenal dengan istilah intertekstualitas. Sementara itu, Culler (1983: 103), mengemukakan bahwa intertekstualitas menuntut perhatian tentang pentingnya teks-teks lain karena pada hakikatnya suatu karya sastra memiliki makna hanya karena adanya hal-hal tertentu yang telah ditulis sebelumnya. Dari pengertian di atas, dapat disimpulkan bahwa untuk memahami suatu teks, pembaca perlu mempertimbangkan pentingnya teks yang menjadi latar belakang sebuah teks (hipogram).

Hipogram potensial dalam drama Faust I adalah matriks yang merupakan inti teks atau kata kunci, yang dapat berupa satu kata, frasa, atau kalimat sederhana. Oleh karena itu, hipogram potensial 
dalam drama Faust I sama dengan matriks yang sudah disebutkan di atas, yakni perjanjian seorang manusia dengan setan agar bisa mendapatkan makna kehidupan yang sesungguhnya.

Drama Faust I adalah drama yang kaya akan hipogram. Yang menjadi hipogram aktual drama Faust I adalah dalam kisah Ayub dalam Injil, cerita rakyat Historia von D. Johann Fausten yang diterbitkan oleh Johann Spies, drama The Tragical History of Doktor Faustus oleh Christopher Marlowe, kisah nyata pembunuhan anak (Kindesmörderin) dan gerakan Freemasonry (Freimauer). Dengan melihat hubungan intertekstual drama Faust I dengan hipogram-hipogramnya dapat disimpulkan bahwa ada beberapa gagasan yang diambil oleh Goethe yang kemudian dituangkan dalam drama Faust I.

Gagasan yang diteruskan oleh Goethe dari kisah Ayub dalam Injil adalah gagasan tentang setan yang menghadap Tuhan dan meminta izin untuk menguji manusia dan Tuhan mengizinkan setan untuk menguji manusia. Dalam kitab Ayub di dalam Injil halaman 15, tertera dengan jelas bagaimana setan (dalam Injil disebut iblis) menghadap Tuhan dan meminta izin untuk menguji ketaatan Ayu. Permintaan izin setan dan izin yang diberikan Tuhan kepada setan untuk menggoda manusia tersebut, kemudian ditransformasikan oleh Goethe dalam drama Faust I, dijadikan satu adegan tersendiri, yakni pada pra-adegan dua berjudul Prolog im Himmel (Prolog di Surga). Di dalam pra-adegan tersebut, Mephistopheles meminta izin kepada Tuhan untuk menggoda Faust, setelah terlebih dahulu menjelek-jelekkan sifat manusia (Goethe, 1982: 10-13).

Dari cerita rakyat berjudul Historia von D. Johann Fausten yang diterbitkan oleh Johann Spies, gagasan yang diteruskan oleh Goethe adalah gagasan manusia yang mengadakan persekutuan dengan setan. Kedua teks, yakni cerita rakyat Historia von D. Johann Fausten yang diter- bitkan oleh Johann Spies dan Faust I karya Goethe, mengetengahkan permasalahan yang sama, yakni persekutuan manusia yang bernama doktor Faust/Faust dengan setan bernama Mephistopheles. Persekutuan tersebut disebabkan keterbatasannya sebagai manusia yang merasa belum bisa memenuhi kebutuhan hidupnya.

Gagasan yang diteruskan oleh Goethe dari drama The Tragical History of Doktor Faustus oleh Christopher Marlowe adalah gagasan tentang manusia yang mengadakan persekutuan dengan setan dan persamaan bentuk jenis sastra yaitu drama. Kedua teks, yakni drama The Tragical History of Doctor Faustus karya Christopher Marlowe dan drama Faust I karya Goethe, mempunyai persamaan dalam hal bentuk genre sastra, yakni drama, meskipun struktur dramanya berbeda. Selain itu, dari dua teks, terlihat tanda persamaan gagasan tentang manusia bernama Doktor Faust/Faustus yang mengikatkan diri kepada setan. Alasan Doktor Faust/Faustus mengadakan persekutuan dengan setan juga mempunyai kesamaan, yakni keinginannya untuk menguasai ilmu pengetahuan karena ketidakpuasannya mempelajari berbagai ilmu sehingga kemudian memutuskan untuk mempelajari ilmu gaib (Magie/magic) dan dilanjutkan pertaliannya dengan setan.

Dari kisah nyata pembunuhan anak (Kindesmörderin) yang dilakukan oleh Susanna, gagasan yang diteruskan oleh Goethe adalah gagasan tentang wanita yang membunuh anak yang baru dilahirkan. Fenomena wanita pembunuh anaknya yang terjadi secara nyata dan dilakukan oleh Susanna tersebut, ditegaskan lagi oleh Goethe dalam drama Faust I. Penegasan tersebut mempunyai arti bahwa kisah wanita yang tega membunuh anaknya sendiri, merupakan kejadian yang manusiawi dan bisa terjadi pada siapa saja, apalagi bagi wanita yang bermasalah seperti Susanna dan Gretchen. 
Dari gerakan Freemasonry (Freimauer), Goethe mengambil gagasan humanisme sekuler dan gagasan setan yang berkarakter lebih demokratis, dinamis, dan positif. Humanisme sekuler dalam ajaran Freemasonry menekankan bahwa manusia adalah makhluk hebat yang dapat memenuhi segala kebutuhan tanpa campur tangan Tuhan. Pemikiran tersebut mempengaruhi Goethe sehingga dalam drama Faust I terlihat bagaimana Faust berusaha menjadikan dirinya manusia yang terlepas dari hubungannya dengan Tuhan. Ambisinya untuk menguasai alam semesta merupakan hal yang mustahil bisa dilakukan oleh manusia karena hanya Tuhanlah yang bisa melakukan hal tersebut. Bahkan ketika Faust merasa sampai pada puncak keterbatasannya karena ketidaksanggupannya menyingkap rahasia alam semesta, dia justru merasa perlu memanggil ruh/setan agar membantu mengatasi keterbatasannya. Setan dalam drama Faust I digambarkan sebagai lambang keberanian, kebebasan, dan demokrasi karena berani mengajukan pertaruhan kepada Tuhan. Dengan berani mengajak Tuhan bertaruh, berarti setan adalah pelopor kebebasan dan demokrasi di hadapan Tuhan.

Dari hubungan intertekstual drama Faust I dengan berbagai teks yang menjadi hipogramnya, dapat disimpulkan bahwa drama Faust I adalah drama yang mengetengahkan persoalan kemanusiaan sehingga apa yang terjadi pada Faust, bisa terjadi pada manusia lainnya. Permasalahan pokok yang terjadi pada tokoh-tokohnya bermula dari keterbatasannya sebagai manusia sehingga untuk mengatasi keterbatasannya, manusia selalu membutuhkan bantuan pihak lain. Hubungan manusia dengan setan dalam drama Faust I terjadi karena hasratnya untuk menguasai rahasia alam semesta (ilmu pengetahuan), berhadapan dengan keterbatasannya sehingga akhirnya meminta bantuan setan dan bersekutu dengannya. Hasrat Faust untuk menguasai ilmu pengetahuan (dan teknologi), menjadikannya simbol manusia modern yang meletakkan ilmu pengetahuan dan teknologi di atas segala-galanya. Pemujaan terhadap ilmu pengetahuan dan teknologi menyebabkan manusia menisbikan kekuasaan Tuhan dan mengutamakan kekuatan setan untuk mencapai tujuannya. Hal ini seperti mengisyaratkan bahwa manusia tidak memerlukan agama lagi karena manusia adalah makhluk unggul, yang bisa mengatasi permasalahan hidup tanpa campur tangan Tuhan.

\section{SIMPULAN}

Dari pembacaan terhadap drama Faust I dengan menggunakan teori Semiotika Riffaterre dapat disimpulkan bahwa drama Faust I adalah drama karya periode klasik di Jerman yang mengetengahkan berbagai tanda penting, tentang tragedi manusia yang mengadakan hubungan dengan setan. Hubungannya dengan setan disebabkan keterbatasannya sebagai manusia. Keterbatasan manusia tidak akan menyebabkan manusia menempuh jalan yang sesat, jika manusia tersebut mempunyai kepercayaan yang kuat kepada Tuhan. Keberadaan setan bisa mengatasi keterbatasan yang dipunyai oleh manusia karena setan mempunyai beberapa kelebihan yang tidak dimiliki oleh manusia. Akan tetapi, dengan mengadakan hubungan dan meminta bantuan kepada setan berarti manusia telah dikalahkan oleh setan dan kepercayannya kepada Tuhan telah ternodai.

Dengan teori Semiotika Rifftaerre ini, makna drama Faust I menjadi semakin lengkap karena drama Faust I juga dilihat dari hipogram atau teks-teks yang menjadi latar belakangnya dan dilihat dari hubungan interteksnya. Dari hubungan interteks dengan teks-teks yang hipogram tersebut semakin jelas terlihat bahwa persoalan yang dialami tokoh Faust adalah persoalan manusia yang universal karena 
bisa terjadi pada siapapun. Jika manusia merasa dirinya unggul (Übermensch) manusia merasa tidak memerlukan Tuhan lagi dalam mengatasi permasalah hidup yang dialaminya. Tokoh setan Mephistopheles adalah perlambang sesuatu kekuatan yang lebih dibutuhkan manusia, dan kekuatan tersebut bisa muncul dalam wujud apa pun juga.

\section{UCAPAN TERIMA KASIH}

Artikel ini diangkat dari Tesis tahun 2008 dari Program Magister Sastra UGM. Untuk itu, ucapan terima kasih disampaikan kepada Dosen Pembimbing Bapak Prof Dr. Rahmat Djoko Pradopo yang telah memberikan bimbingan, arahan, dan saran dalam penelitian ini. Selanjutnya, ucapan terimakasih diucapkan kepada reviewer anonim yang telah membaca, mengoreksi dan memberi masukan penulisan artikel ini.

\section{DAFTAR PUSTAKA}

Baumann, Barbara. 2000. Deutsche Literatur in Epochen. Ismaning, Jerman: Max Hueber Verlag.
Culler, Jonathan. 1983. The Pursuit of Sign, Semiotics, Literature, Deconstruction. London: Rotlegde \& Kegan Paul.

Freund, Winfried. 2000. Deutsche Literatur. Köln: DuMont Buchverlag.

Goethe, Johann Wolfgang. 1982. Faust. Der Tragödie erster und zweiter Teil. Zürich: Dialogenes Verlag AG.

Kristeva, Julia. 1980. Desire in Language : A Semiotic Approach to Literature and Art. Oxford: Basil Blackwell.

Marquass, Reinhard. 1998. Dramentexte analysieren. Mannheim: Duden Verlag.

Moleong, Lexi J. 2007. Metodologi Penelitian Kuantitatif. Bandung: Remaja Rosdakarya.

Pradopo, Rahmat Djoko. 2005. Beberapa Teori Sastra, Metode Kritik, dan Penerapannya. Yogyakarta: Pustaka Pelajar.

Pradopo, Rahmat Djoko. 2005. Pengkajian Puisi. Yogyakarta: Gadjah Mada University Press.

Riffaterre, Michael. 1984. Semiotics of Poetry. Bloomington and London: Indianan University Press.

Rötzer, Hans Gerd. 1992. Geschichte der deutschen Literatur. Bamberg: C.C. Buchners Verlag. 